\title{
Effects of miR-135a-5p and miR-141 on proliferation, invasion and apoptosis of colorectal cancer SW620 cells
}

\author{
JIAN WANG ${ }^{*}$, JING YANG ${ }^{*}$, HENG ZHANG, YUSHENG LIAO, DAN XU and SONGLIN MA \\ Department of Gastroenterology, The Central Hospital of Wuhan, Tongji Medical College, \\ Huazhong University of Science and Technology, Wuhan, Hubei 430030, P.R. China
}

Received May 24, 2019; Accepted February 4, 2020

DOI: $10.3892 / \mathrm{ol} .2020 .11598$

\begin{abstract}
Effects of miR-135a-5p and miR-141 on the biological function of colorectal cancer SW620 cells were investigated. Fifty-four specimens of cancer tissues and 54 specimens of corresponding adjacent tissues in colon cancer patients who were treated in The Central Hospital of Wuhan from March 2014 to March 2015 were collected. RT-PCR was used to detect the expression levels of miR-135a-5p and miR-141 in cancer tissues and adjacent tissues. The miR-135a-5p inhibitor and miR-141 mimic carriers were established. The cell proliferation was detected by CCK8, the invasion ability of cells in vitro was evaluated by Transwell chamber, and cell apoptosis of each group was detected by flow cytometry. The results of RT-qPCR showed that expression levels of miR-135a-5p in colorectal cancer tissues were significantly higher than those in adjacent tissues, the expression levels of miR-141 in colorectal cancer tissues were significantly lower than those in adjacent tissues, and the difference was statistically significant $(\mathrm{P}<0.001)$. The cell survival rates of the miR-135a-5p inhibitor group and the miR-141 mimic group were significantly lower than those of the NC group and the blank group 48 and $72 \mathrm{~h}$ after transfection $(\mathrm{P}<0.001)$. The number of invasive cells in the miR-135a-5p inhibitor group and the miR-141 mimic group was significantly lower than that in the blank group and the $\mathrm{NC}$ group $(\mathrm{P}<0.001)$. Apoptosis rate was significantly higher than that of the NC group and the blank group $(\mathrm{P}<0.001)$. In conclusion, low expression levels of miR-135a-5p and miR-141 in colorectal adenomas suggested that miR-135a-5p and miR-141 could act as tumor suppressors in the development of colorectal adenomas; miR-135a-5p and miR-141 inhibited
\end{abstract}

Correspondence to: Dr Songlin Ma, Department of Gastroenterology, The Central Hospital of Wuhan, Tongji Medical College, Huazhong University of Science and Technology, 26 Shengli Street, Jiang'an, Wuhan, Hubei 430030, P.R. China

E-mail:mhjr87@163.com; songlinma8887@sina.com

*Contributed equally

Key words: miR-135a-5p, miR-141, colon cancer, SW620 cell, proliferation, apoptosis, invasion the proliferation and invasion of colon cancer SW620 cells and promoted apoptosis of colon cancer cells.

\section{Introduction}

Colorectal cancer is one of the common malignant tumors of the digestive system in the gastrointestinal tract (1), and its morbidity rate ranks second only to gastric cancer (2). With the development of social economy and the impact of people's poor living and eating habits, the morbidity of colorectal cancer shows lower average onset age. Early detection, early diagnosis and early radical treatment are the key to the treatment of colorectal cancer, but because the clinical features of early colorectal cancer are easily overlooked by patients, most patients have advanced colorectal cancer when they are diagnosed (3). Patients with advanced colorectal cancer have a poor prognosis and a high mortality rate $(4,5)$. At present, the treatment of colorectal cancer commonly used in clinical practice is mainly based on surgical excision, irradiation, and combination of chemotherapy and radiotherapy $(6,7)$. Recent in-depth investigations of the mechanism of colorectal cancer, is expected to provide new ideas and targets for the treatment and prognosis of colorectal cancer by regulating tumor suppressor genes or cancer-promoting genes to affect the occurrence and development of cancer $(8,9)$.

MicroRNAs (miRNAs) are a class of endogenous noncoding single-stranded RNAs that have tumor promotion or tumor inhibition function $(10,11)$. Current research indicates that miR-135a-5p plays a role in tumor suppressor miRNAs in gallbladder carcinoma tissues (12). In recent years, there have been reports that the inhibition of miR-214 expression significantly inhibits the proliferation of colorectal cancer, process of the cell cycle, and development of migration (13). Some researchers have confirmed that miR-141 is abnormally expressed in cancerous symptoms in cervical cancer, ovarian cancer and bladder cancer, and the expression levels of miR-141 in tumor tissues were much lower than those in normal tissues (14). However, the biological characteristics of colorectal cancer SW620 cells, the correlation between miR-135a-5p and miR-141 and specific effects of expression changes of miR-135a-5p and miR-141 on the biological characteristics of colorectal cancer SW620 cells were not clear. Therefore, this study investigated the characteristics of expression levels of miR-135a-5p and miR-141 in colorectal cancer 
and effects of the biological characteristics of colorectal cancer SW620, in order to provide a new theoretical basis for the diagnosis and treatment of colorectal cancer in molecular biology.

\section{Patients and methods}

Data collection. Fifty-four specimens of cancer tissues and 54 specimens of corresponding adjacent tissues of colorectal cancer patients who were treated in The Central Hospital of Wuhan (Wuhan, China) from March 2014 to March 2015 were selected. The inclusion and exclusion criteria were as follows: Patients had normal liver and kidney function and no other malignant tumors; the tissue sections were diagnosed as colorectal cancer tissues or adjacent tissues by the pathology department of The Central Hospital of Wuhan, and all specimens were placed in liquid nitrogen immediately after excision. Patients who had undergone chemotherapy, immunotherapy, and radiotherapy before surgery were excluded. Patients and their families were informed in advance and informed consent forms were signed before the study. The study was approved by the Ethics Committee of The Central Hospital of Wuhan.

\section{Main reagents, instruments and detection methods}

Main reagents and instruments. Human colorectal cancer cell line SW620 cells were from Shanghai Enzyme Research Biotechnology Co., Ltd.; TRIzol reagents were from Invitrogen; Thermo Fisher Scientific, Inc.; RT-qPCR kit and miScript reverse transcription kit were from Dalian Takara; HBS-1096A enzyme-mark analyzer was from Nanjing Detie Experimental Equipment Co., Ltd.; real-time quantitative PCR instrument was from Bio-Rad Laboratories, Inc.; DMEM medium was from Gibco; Thermo Fisher Scientific, Inc.; Fetal bovine serum (FBS) and trypsin were from Hyclone, GE Healthcare; Cell Counting Kit-8 (CCK-8) kit was from Beijing Zhijie Fangyuan Technology Co., Ltd.; Transwell chamber was from BD Biosciences; CyFlow Cube 8 flow cytometry was from Partec, Germany; primer sequences of miR-135a-5p and miR-141 and internal reference U6, miRNA negative control and other carriers were designed and synthesized by Shanghai Jima Company (Table I).

Detection of miR-135a-5p and miR-141. RT-PCR was used to detect the expression levels of miR-135a-5p and miR-141 in colorectal cancer tissues and adjacent tissues. Total RNA in tissues was extracted and dissolved in $20 \mu 1$ of DEPC water according to the instructions of TRIzol reagent. The total RNA was then reverse transcribed by a reverse transcription kit, and the reaction system was as follows: M-MIV $1 \mu \mathrm{l}$, Olig(dT) $1 \mu \mathrm{l}$, RNA enzyme inhibitor $0.5 \mu \mathrm{l}$, d NTPs $1 \mu \mathrm{l}$, RNAse free water supplemented to $15 \mu \mathrm{l}$. The incubation was for $60 \mathrm{~min}$ at $38^{\circ} \mathrm{C}$. cDNA $(1 \mu \mathrm{l})$ was taken at $85^{\circ} \mathrm{C}$ for $5 \mathrm{sec}$; the synthesized cDNA was used as a template for RT-qPCR amplification; preparation of PCR reaction system was as follows: $10 \times 2.5 \mu 1$ PCR buffer, dNTPs $1 \mu 1$, upstream primers $1 \mu \mathrm{l}$, downstream primers $1 \mu \mathrm{l}$, Taq DNA Polymerase $0.25 \mu \mathrm{l}, \mathrm{ddH}_{2} \mathrm{O}$ was made up to $25 \mu \mathrm{l}$. Reaction conditions were as follows: pre-denaturation at $95^{\circ} \mathrm{C}$ for $15 \mathrm{~min}$, denaturation at $95^{\circ} \mathrm{C}$ for $15 \mathrm{sec}$, annealing at $60^{\circ} \mathrm{C}$ for $30 \mathrm{sec}$, with a total of 35 cycles; finnally, extended at $72^{\circ} \mathrm{C}$ for $15 \mathrm{~min}$; three replicate wells were set for each sample for 3 repeated experiments, and miR-135a-5p and miR-141 were used with U6 as an internal reference. After the end of the reaction, the amplification curve and the melting curve of the Real-time PCR were confirmed, and the relative amount of the target gene was calculated based on the resulting parameters. The quantification of the target gene was calculated by $2^{-\Delta C t}$.

Cell culture and transfection. The human colorectal cancer SW620 cells were placed in a medium containing $10 \%$ FBS DMEM, placed in a $\mathrm{CO}_{2}$ incubator at $37^{\circ} \mathrm{C}$, and when the fusion growth of cells reached $50 \%, 25 \%$ trypsin was added for digestion; after the digestion was completed, it was placed in the medium to continue the culture and complete the passage. Cells in logarithmic phase were transfected, grouped before transfection, and cells that were not transfected were set as blank group, negative RNA control (NC group), miR-135a-5p inhibitor group and miR-141 mimic group; Lipofectamine 2000 and DNA were diluted and mixed according to the Lipofectamine 2000 manufacturer's kit instructions; NC, miR-135a-5p inhibitor and miR-141 mimic were transfected into SW620 cells by Lipofectamine 2000, and incubated for $5 \mathrm{~min}$ at room temperature; finally, the mixture was mixed with cells and transfected under the condition of $37^{\circ} \mathrm{C}$ and $\mathrm{CO}_{2}$; RT-qPCR was used to test the expression levels of miR-135a-5p in SW620 cells transfected with miR-135a-5p or miR-141 in miR-135a-5p inhibitor group, miR-141 mimic group, NC group and blank group $48 \mathrm{~h}$ after transfection.

Cell proliferation detected by CCK8. SW620 cell lines in each group were inoculated in a 96-well plate at $100 \mu \mathrm{l}$ per well $48 \mathrm{~h}$ after transfection; cells were diluted into $4 \times 10^{3}$ cells $/ \mathrm{ml}$ after pancreas digestion, and then the culture plate was placed in a cell culture incubator for $24 \mathrm{~h}$; the old medium was discarded; finally these samples were added to groups of miR-135a-5p inhibitor, miR-141 mimic, NC and blank. The culture plate was taken out and the old culture medium was discarded 48 and $72 \mathrm{~h}$ after culture; $100 \mu \mathrm{l}$ of CCK8 solution was added to each well; the absorbance was measured at $450 \mathrm{~nm}$ with a microplate reader to detect cell proliferation after $4 \mathrm{~h}$ of incubation in a $37^{\circ} \mathrm{C}$ incubator, and the experiment was repeated three times.

Invasive ability of cells in vitro detected by Transwell chamber. Cells were digested by Trypsin, then centrifuged at $8,000 \mathrm{x} \mathrm{g}$ for $5 \mathrm{~min}$ at $4^{\circ} \mathrm{C}$ and the culture medium was discarded; cells were washed twice with FBS, then the serum-free medium containing BSA was resuspended, and the cell density was adjusted to $5 \times 10^{4} / \mathrm{ml}$. Medium containing FBS $(1 \mathrm{ml})$ was added to the lower chamber of a 6 -well plate; $2 \mathrm{ml}$ of cell suspension was added to Transwell chamber; after $24 \mathrm{~h}$ of routine incubation, cells in the Transwell chamber were wiped off with a cotton swab; after the Transwell chamber was dried, the film was sealed and observed by microscopic techniques.

Cell apoptosis in each group detected by flow cytometry. After trypsin digestion, cells in miR-135a-5p inhibitor group, miR-141 mimic group and $48 \mathrm{~h}$ after NC treatment were collected; it 
Table I. Primer sequences of miR-135a-5p, miR-141 and internal reference U6.

\begin{tabular}{lll}
\hline Name & \multicolumn{1}{c}{ Forward primers } & \multicolumn{1}{c}{ Reverse primers } \\
\hline miR-141 & 5'-GAGCGGACCTTCAGATGAGA-3' & 5'-GTGCAGGGTCCGAGGT-3' \\
miR-135a-5p & 5'-ACACTCCAGCTGGGGTGCATTGTAGTTGCA-3' & 5'-TGGTGTCGTGGAGTCG-3' \\
U6 & 5'-CTCGCTTCGGCAGCACA-3' & 5'-AACGCTTCACGAATTTGCGT-3' \\
Blank group & 5'-UUCCGGUCCUUGCGUGGUTT3-3' & 5'-ACGCAUGAGGUUCGTCCUGT-3' \\
miRNA negative control & 5'-UUCAAUCCCGCGACGUTT-3' & 5'-ACGACGUGCGACUUGAGAATT-3'
\end{tabular}

Table II. General clinical data of patients.

\begin{tabular}{lc}
\hline Item & {$[\mathrm{n}(\%)]$} \\
\hline Age, years & \\
$\leq 56$ & $14(25.93)$ \\
$>56$ & $40(74.07)$ \\
Sex & \\
Male & $30(55.56)$ \\
Female & $24(44.44)$ \\
Education & \\
Bachelor's degree or above & $45(83.33)$ \\
Undergraduate or below & $9(16.67)$ \\
Family history of colorectal cancer & \\
Yes & $10(8.52)$ \\
No & $44(81.48)$ \\
Smoking & \\
Yes & $36(66.67)$ \\
No & $18(33.33)$ \\
Drinking & \\
Yes & $38(70.37)$ \\
No & $16(29.63)$ \\
Clinical stage & \\
I-II & $39(72.22)$ \\
III-IV & $15(17.78)$ \\
Lymphatic metastasis & \\
Yes & \\
No & \\
\hline & \\
\hline & \\
\hline
\end{tabular}

was fixed for $24 \mathrm{~h}$ under ethanol with the concentration of $75 \%$ and room temperature of $20^{\circ} \mathrm{C}$, with a constant temperature of $4^{\circ} \mathrm{C}$, ethanol was discarded after centrifugation at 2,500 $\mathrm{xg}$ for $5 \mathrm{~min}$; FBS was used again to rinse it, it was centrifuged with a constant temperature of $4^{\circ} \mathrm{C}$ and at the speed of $2,500 \mathrm{xg}$ for $5 \mathrm{~min}$, then the supernatant was discarded; $500 \mu \mathrm{l}$ DNA staining solution was added to all samples and thoroughly mixed; finally, the prepared solution was transferred to a flow tube and incubated in the dark for $30 \mathrm{~min}$ and detected by CyFlow Cube 8 flow cytometry.

Statistical analysis. SPSS 17.0 (Beijing Strong-Vinda Information Technology Co., Ltd.) software system was applied in statistical analysis; the counting data were expressed

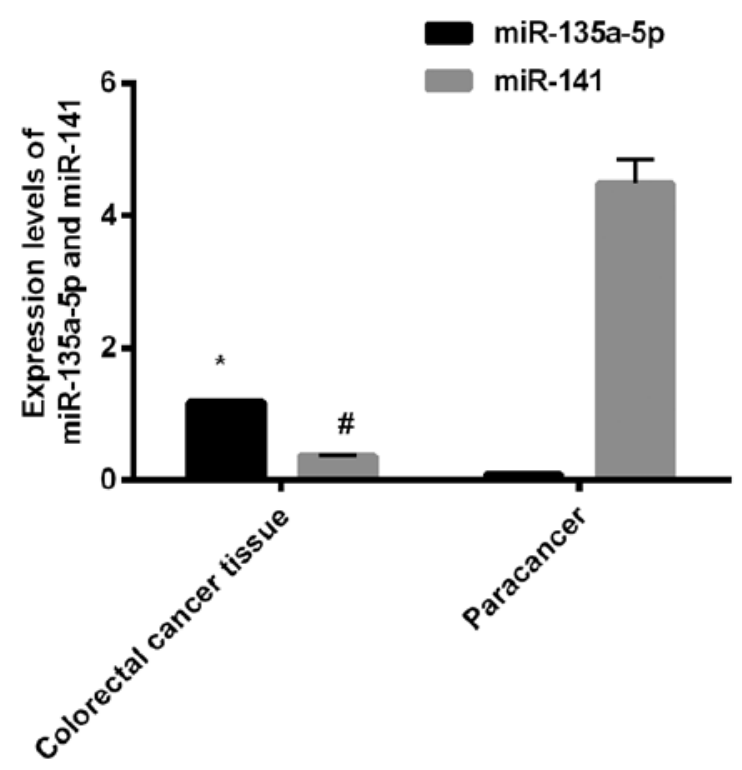

Figure 1. Expression levels of miR-135a-5p and miR-141 in colorectal cancer tissues and adjacent tissues. RT-qPCR was used to detect expression levels of miR-135a-5p and miR-141. ${ }^{*} \mathrm{P}<0.001$, the expression levels of miR-135a-5p in colorectal cancer tissues were significantly higher than those in adjacent tissues, ${ }^{\#} \mathrm{P}<0.001$, the expression levels of miR-141 in colorectal cancer tissues were significantly lower than those in adjacent tissues, with statistically significant difference.

as [n (\%)], and the comparison between the two groups was performed by $\chi^{2}$ test; the measurement data were expressed by (mean $\pm \mathrm{SD}$ ), and the comparison between groups was performed by $\mathrm{t}$-test or $\mathrm{F}$ test; $\mathrm{P}<0.05$ was considered to indicate a statistically significant difference.

\section{Results}

General data of patients (Table II)

Expression levels of miR-135a-5p and miR-141 in colorectal cancer tissues and adjacent tissues. The expression levels of miR-135a-5p in colorectal cancer tissues and adjacent tissues were, respectively, $1.18 \pm 0.02$ and $0.10 \pm 0.02$; the expression levels of miR-141 in colorectal cancer tissues and adjacent tissues were, respectively, $0.37 \pm 0.01$ and $4.48 \pm 0.36$. The expression levels of miR-135a-5p in colorectal cancer tissues were significantly higher than those in adjacent tissues; the expression levels of miR-141 in colorectal cancer tissues were significantly lower than those in adjacent tissues, and differences between the two groups were statistically significant $(\mathrm{P}<0.001)$ (Fig. 1). 
A

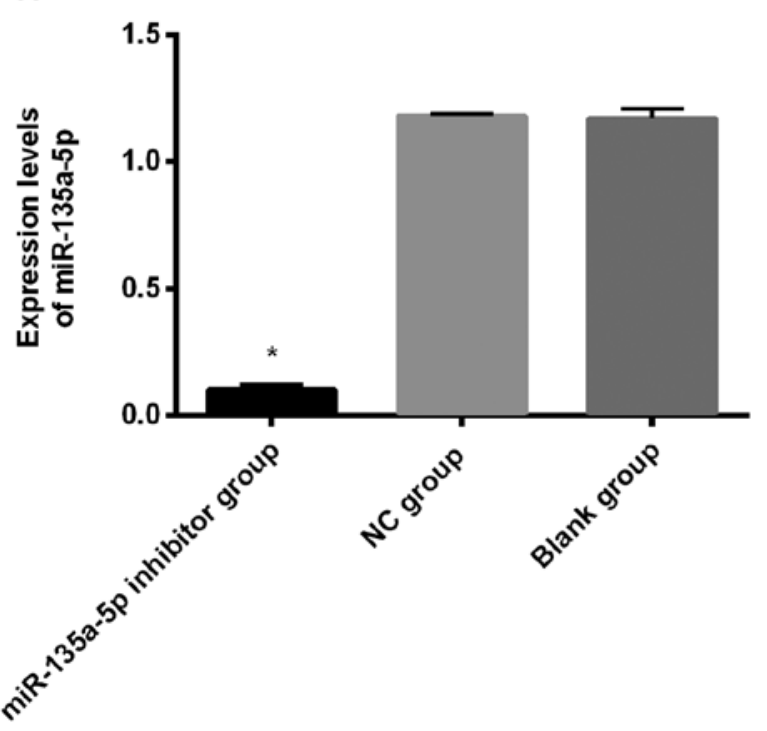

B

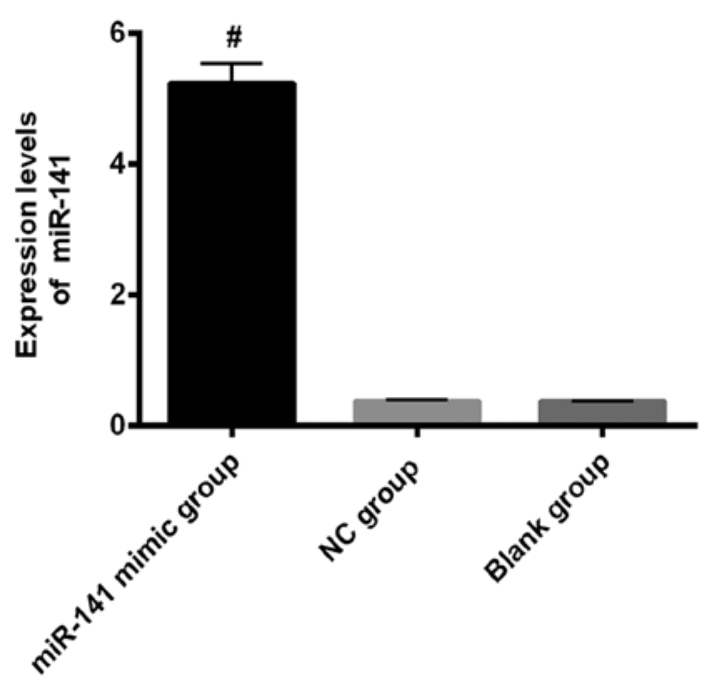

Figure 2. Relative expression levels of miR-135a-5p and miR-141 in the cells of each group after transfection. RT-PCR was used to detect the expression levels of miR-135a-5p and miR-141 in each group. (A) The expression levels of miR-135a-5p in the miR-135a-5p inhibitor group were significantly lower than those in the NC group and the blank group, and the difference was statistically significant ( $\mathrm{P}<0.001)$. (B) The expression levels of miR-141 in the miR-141 mimic group were significantly higher than those in the NC group and the blank group, and the difference was statistically significant $\left({ }^{\#} \mathrm{P}<0.001\right)$. NC, negative RNA control.

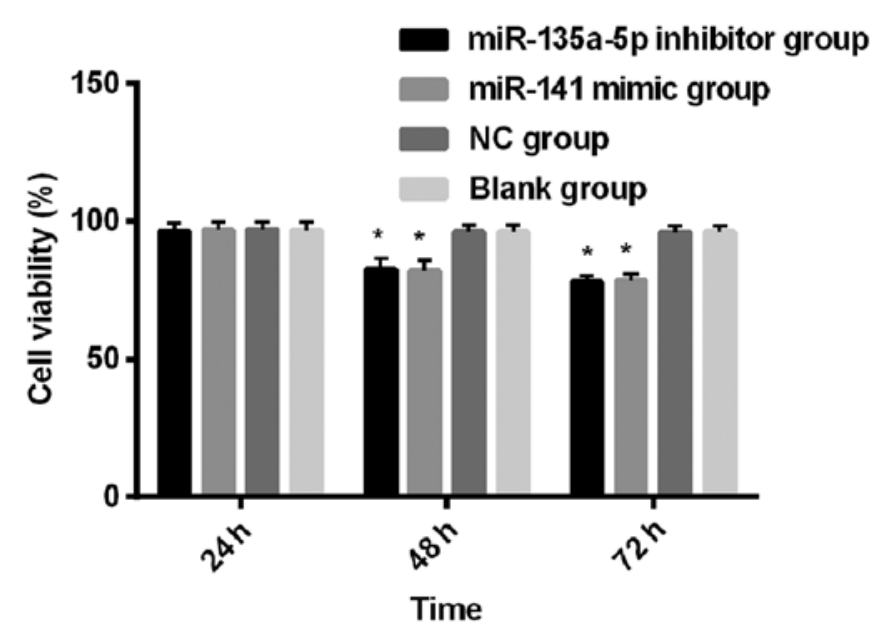

Figure 3. Comparison of proliferation ability of colorectal cancer SW620 cells in each group after transfection. Cell proliferation was detected by CCK8. " $\mathrm{P}<0.001$, the cell survival rates of the miR-135a-5p inhibitor group and the miR-141 mimic group were significantly lower than those of the NC group and the blank group at 48 and $72 \mathrm{~h}$. NC, negative RNA control.

Relative expression levels of miR-135a-5p and miR-141 in each group after transfection. The expression levels of miR-135a-5p in the miR-135a-5p inhibitor group, $\mathrm{NC}$ group and blank group were, respectively, $0.10 \pm 0.01,1.18 \pm 0.01$ and $1.17 \pm 0.04$; the expression levels of miR-135a-5p in the miR-135a-5p inhibitor group were significantly lower than those in the NC group and blank group, and the difference was statistically significant $(\mathrm{P}<0.001)$. The expression levels of miR-141 in the miR-141 mimic group, $\mathrm{NC}$ group and blank group were, respectively, $5.23 \pm 0.31,0.37 \pm 0.02$ and $0.37 \pm 0.01$; the expression levels of miR-141 in the miR-141 mimic group were significantly higher than those in the $\mathrm{NC}$ group and the blank group, and the difference was statistically significant $(\mathrm{P}<0.001)$. There was

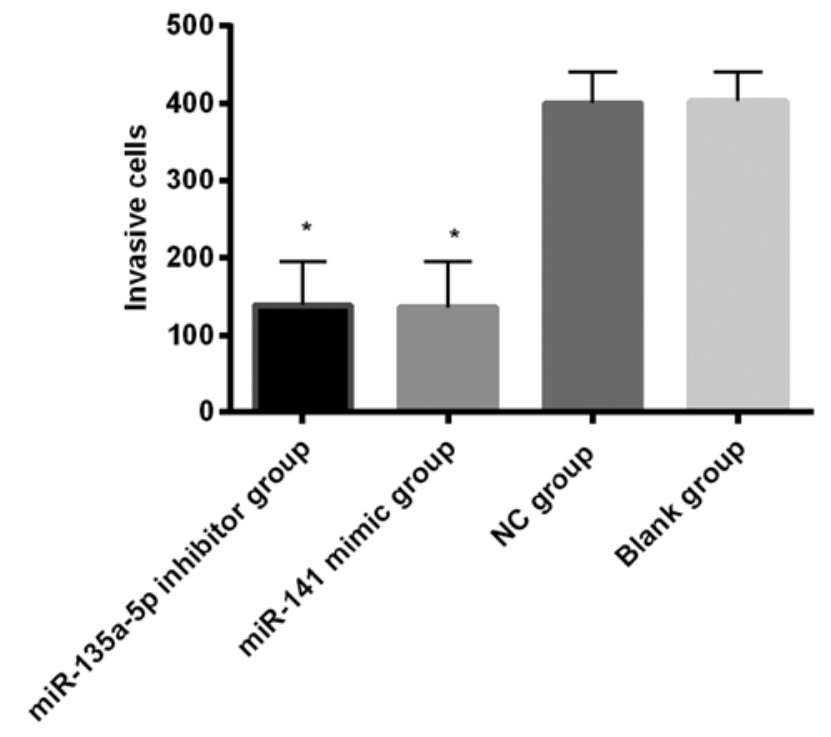

Figure 4. Comparison of invasion of colorectal cancer SW620 cells in each group. Transwell chamber was used to detect the invasion ability of cells in vitro. ${ }^{*} \mathrm{P}<0.001$, the number of invasive cells in the miR-135a-5p inhibitor group and the miR-141 mimic group was significantly lower than that in the blank group and the NC group, and the difference was statistically significant. NC, negative RNA control.

no significant difference in the expression levels of miR-141 and miR-135a-5p between the NC group and the blank group (P>0.05) (Fig. 2).

Comparison of survival rate of colorectal cancer SW620 cells after transfection. The results of intra-group comparison showed that the cell survival rates of the miR-135a-5p inhibitor group and the miR-141 mimic group showed a gradual downward trend from 24 to $72 \mathrm{~h}$, and the differences were 

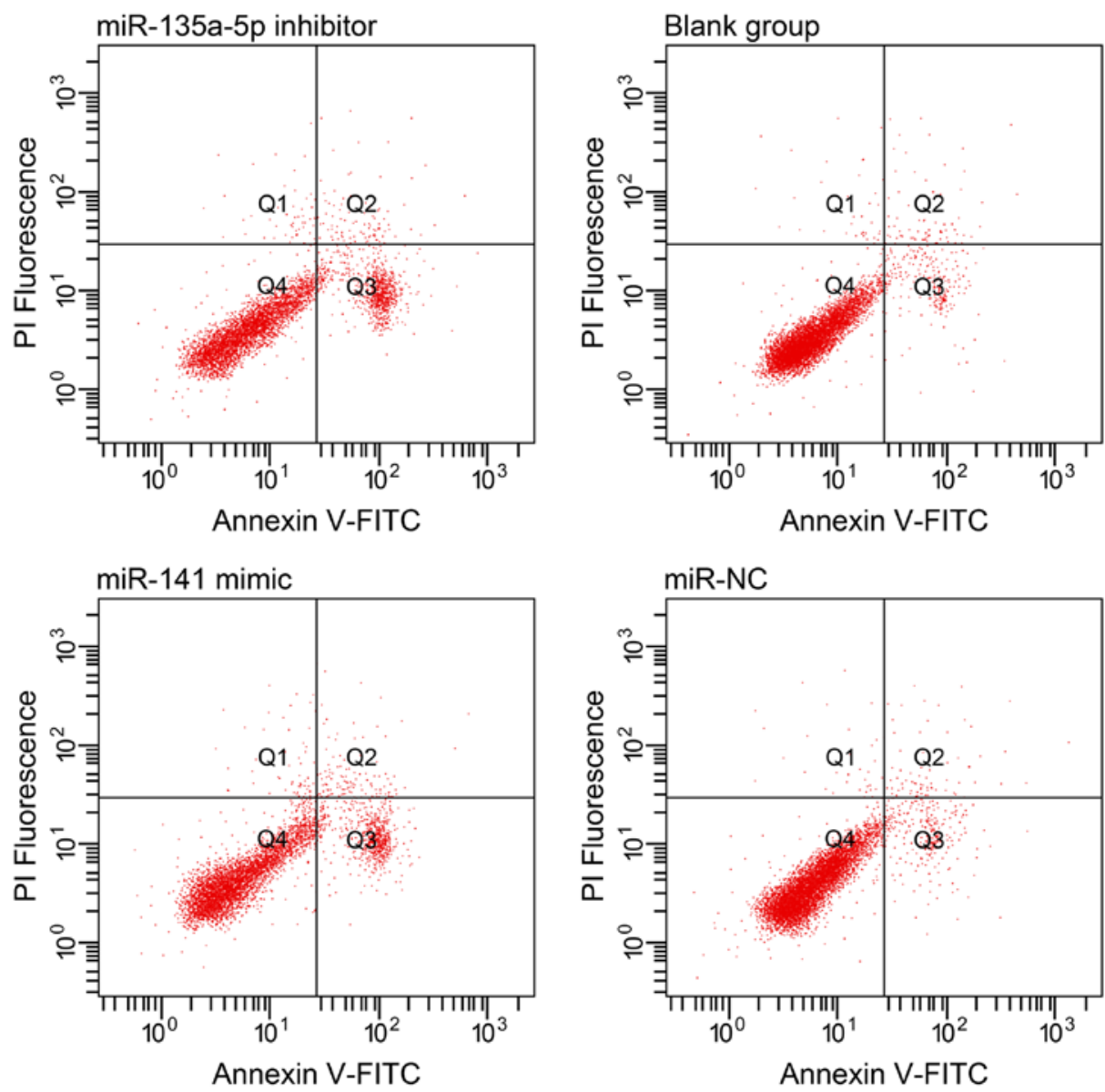

Figure 5. Apoptotic rate (\%) of each group.

statistically significant at different time points in the three groups $(\mathrm{P}<0.001)$; the cell survival rates of the $\mathrm{NC}$ group and blank group at 72 and $48 \mathrm{~h}$ were significantly lower than those of $24 \mathrm{~h}$, and the differences were statistically significant $(\mathrm{P}<0.05)$. The results of group comparisons showed that the cell survival rates of the miR-135a-5p inhibitor group, miR-141 mimic group, NC group and blank control group were compared for $24 \mathrm{~h}$, and differences were not statistically significant $(\mathrm{P}>0.05)$. The cell survival rates of the miR-135a-5p inhibitor group and miR-141 mimic group were significantly lower than those of NC group and blank group at 48 and $72 \mathrm{~h}$ $(\mathrm{P}<0.001)$, and there was no significant difference between the $\mathrm{NC}$ group and blank group at 48 and $72 \mathrm{~h}(\mathrm{P}>0.05)$ (Fig. 3).

Comparison of invasion of colorectal cancer SW620 cells in each group. The number of invasion cells in the miR-135a-5p inhibitor group, miR-141 mimic group, NC group and blank control group was, respectively, $138.80 \pm 56.04,136.24 \pm 58.44$, $400.23 \pm 40.33$ and $403.10 \pm 38.00$; the number of invasion cells in miR-135a-5p inhibitor group and miR-141 mimic group was significantly lower than that in the blank group and $\mathrm{NC}$ group, and the differences were statistically significant $(\mathrm{P}<0.001)$ (Fig. 4).

Comparison of apoptosis ability of colorectal cancer SW620 cells in each group after transfection. The apoptosis rates of miR-135a-5p inhibitor group and miR-141 mimic group were, respectively, $23.06 \pm 2.64 \%$ and $22.41 \pm 4.39 \%$, but were significantly higher than those of the NC group $4.10 \pm 0.20 \%$ and blank group $3.99 \pm 0.43 \%(\mathrm{P}<0.001)$. There was no significant difference in apoptosis rates between the NC group and blank group ( $\mathrm{P}>0.05)$ (Table III and Fig. 5).

\section{Discussion}

The biological characteristics of colorectal cancer cells affect the developmental effects of colorectal cancer (15). Among them, proliferation and apoptosis of tumor cells together determine the growth and decline of tumor and control the growth rate of tumors (16). Numerous studies have shown that cell proliferation is an important life feature of biological organisms (17). Normal cell proliferation will stop naturally to a certain extent, and cancer cells have uncontrolled characteristics; the non-stop proliferation, invasion and metastasis of cancer cells are the main causes of death in patients with malignant tumors (18). miRNAs play an important role in carcinogenesis and tumor progression, and expression of miRNAs affects the invasiveness of tumor cells (19). Changes in the expression of miRNAs have been shown to be associated with the development and progression of malignant tumors (20). This study analyzed the expression features of miR-135a-5p and miR-141 in colorectal cancer and the effects of miR-135a-5p and miR-141 on the biological function of colorectal cancer SW620 cells, in order to provide a 
Table III. Comparison of apoptotic rate (\%) of each group.

\begin{tabular}{|c|c|c|c|c|c|c|}
\hline Group & miR-135a-5p inhibitor & miR-141 mimic group & NC group & Blank group & F value & P-value \\
\hline Apoptotic rate $(\%)$ & $20.14 \pm 3.32$ & $19.73 \pm 4.01$ & $4.10 \pm 0.20$ & $3.99 \pm 0.43$ & 665.500 & $<0.001$ \\
\hline
\end{tabular}

NC group, negative RNA control group.

new theoretical basis for diagnosis and treatment of colorectal cancer in molecular biology.

In this study, expression levels of miR-135a-5p and miR-141 were first observed in colorectal cancer tissues and adjacent normal tissues. The results showed that the expression levels of miR-135a-5p in colorectal cancer tissues were significantly higher than those in adjacent tissues. The expression levels of miR-141 in colorectal cancer tissues were significantly lower than those in adjacent tissues, with statistically significant difference. Similar studies also confirmed that the expression levels of miR-141 mRNA in renal cell carcinoma tissues were significantly lower than those in adjacent tissues and normal tissues. The results of Wang et al (21) showed that the expression levels of miR-135a-5p in colorectal cancer tissues were significantly higher than those in adjacent tissues, and differences were statistically significant. In order to investigate the specific effects of expression changes of miR-135a-5p and miR-141 in colorectal cancer, we performed RT-qPCR to detect the expression levels of miR-135a-5p and miR-141 in transfected human colorectal cancer SW620 cells in groups of miR-135a-5p inhibitor, miR-141 mimic, and NC, and the proliferation, invasion and apoptosis of SW620 cells were recorded and regulated after miR-135a-5p and miR-141 were expressed. The expression levels of miR-135a-5p in the miR-135a-5p inhibitor group were significantly lower than those in the NC group and blank group. The expression levels of miR-141 in the miR-141 mimic group were significantly higher than those in the NC group and blank group, with statistically significant difference. Moreover, the cell survival rates of the miR-135a-5p inhibitor group and the miR-141 mimic group were significantly lower than those of the NC group and the blank group at 48 and $72 \mathrm{~h}$.

The biological function of malignant tumor cells is affected by the epithelial-mesenchymal transition process (22); Musavi Shenas et al (23) found that the miR-200 family was closely related to the epithelial-mesenchymal transition process. As a member of the miR-200 family, miR-141 promoted cell transformation from benign to malignant and abnormal proliferation of cells by inhibiting the epithelialmesenchymal transition process (24). Thus, we believe that it is possible to indirectly inhibit the epithelial-mesenchymal transition process of tumor cells and inhibit the action of tumors by overexpressing miR-141. Invasion and apoptosis of colorectal cancer SW620 cells were observed. The number of invasive cells in the miR-135a-5p inhibitor group and miR-141 mimic group was significantly lower than that in the NC group and blank group. The apoptosis rate of the miR-135a-5p inhibitor group and miR-141 mimic group was significantly higher than that of the NC group and blank group. The death in patients with malignant tumors is often caused by invasion and metastasis of cancer cells (25); when the invasion of cancer cells is controlled and the apoptosis rate of cancer cells is accelerated, the continued deterioration of the cancer has been relieved to some extent (26). Similarly, studies on miRNAs and cancer cells confirmed that the overexpression of miR-141 effectively inhibited the number of invading cancer cells, and the amplitude of apoptosis of cancer cells became significantly larger (27). Therefore, we believe that the number of invasive cells and apoptosis rate of human colorectal cancer SW620 cells could be affected by appropriately regulating miRNAs.

In summary, miR-135a-5p is highly expressed in colorectal cancer tissues, and miR-141 expression is low in colorectal cancer tissues; silent expression of miR-135a-5p and overexpression of miR-141 inhibited the proliferation and invasion of human colorectal cancer SW620 cells, and promoted apoptosis of human colorectal cancer SW620 cells. It is concluded that miR-135a-5p and miR-141 are involved in the biological process of human colorectal cancer SW620 cells, and could be used as diagnostic markers and therapeutics targets in colorectal cancer.

\section{Acknowledgements}

Not applicable.

\section{Funding}

No funding was received.

\section{Availability of data and materials}

The datasets used and/or analyzed during the present study are available from the corresponding author on reasonable request.

\section{Authors' contributions}

JW wrote the manuscript. JW and JY performed PCR and CCK8 test. HZ and YL were responsible for Transwell chamber test and flow cytometry. DX and SM contributed to observation indexes analysis. All authors read and approved the final manuscript.

\section{Ethics approval and consent to participate}

The study was approved by the Ethics Committee of The Central Hospital of Wuhan (Wuhan, China). Patients who participated in this research had complete clinical data. Signed informed consents were obtained from the patients and/or the guardians. 


\section{Patient consent for publication}

Not applicable.

\section{Competing interests}

The authors declare that they have no competing interests.

\section{References}

1. Siegel RL, Miller KD, Fedewa SA, Ahnen DJ, Meester RGS, Barzi A and Jemal A: Colorectal cancer statistics, 2017. CA Cancer J Clin 67: 177-193, 2017.

2. Guinney J, Dienstmann R, Wang X, de Reyniès A, Schlicker A Soneson C, Marisa L, Roepman P, Nyamundanda G, Angelino P, et al: The consensus molecular subtypes of colorectal cancer. Nat Med 21: 1350-1356, 2015.

3. Pietrantonio F, Petrelli F, Coinu A, Di Bartolomeo M, Borgonovo K, Maggi C, Cabiddu M, Iacovelli R, Bossi I, Lonati $\mathrm{V}$, et al: Predictive role of BRAF mutations in patients with advanced colorectal cancer receiving cetuximab and panitumumab: A meta-analysis. Eur J Cancer 51: 587-594, 2015.

4. Tauriello DVF and Batlle E: Targeting the microenvironment in advanced colorectal cancer. Trends Cancer 2: 495-504, 2016.

5. Moriarity A, O'Sullivan J, Kennedy J, Mehigan B and McCormick P: Current targeted therapies in the treatment of advanced colorectal cancer: A review. Ther Adv Med Oncol 8: 276-293, 2016.

6. Schmeel FC, Simon B, Sabet A, Luetkens JA, Träber F, Schmeel LC, Ezziddin S, Schild HH and Hadizadeh DR: Diffusion-weighted magnetic resonance imaging predicts survival in patients with liver-predominant metastatic colorectal cancer shortly after selective internal radiation therapy. Eur Radiol 27: 966-975, 2017

7. van Hazel GA, Heinemann V, Sharma NK, Findlay MP, Ricke J, Peeters M, Perez D, Robinson BA, Strickland AH, Ferguson T, et al: SIRFLOX: Randomized phase III trial comparing first-line mFOLFOX6 (plus or minus bevacizumab) versus mFOLFOX6 (plus or minus bevacizumab) plus selective internal radiation therapy in patients with metastatic colorectal cancer. J Clin Oncol 34: 1723-1731, 2016.

8. Mohammadi A, Mansoori B and Baradaran B: The role of microRNAs in colorectal cancer. Biomed Pharmacother 84 705-713, 2016.

9. Tsukamoto M, Iinuma H, Yagi T, Matsuda $\mathrm{K}$ and Hashiguchi $\mathrm{Y}$ : Circulating exosomal microRNA-21 as a biomarker in each tumor stage of colorectal cancer. Oncology 92: 360-370, 2017.

10. Tang W, Wan S, Yang Z, Teschendorff AE and Zou Q: Tumor origin detection with tissue-specific miRNA and DNA methylation markers. Bioinformatics 34: 398-406, 2018.

11. Mansoori B, Mohammadi A, Ghasabi M, Shirjang S, Dehghan R, Montazeri V, Holmskov U, Kazemi T, Duijf P, Gjerstorff M, et al: miR-142-3p as tumor suppressor miRNA in the regulation of tumorigenicity, invasion and migration of human breast cancer by targeting Bach-1 expression. J Cell Physiol 234: 9816-9825, 2019.

12. Li Z, Yu X, Shen J, Law PT, Chan MT and Wu WK: MicroRNA expression and its implications for diagnosis and therapy of gallbladder cancer. Oncotarget 6: 13914-13921, 2015.
13. Hu JL, He GY, Lan XL, Zeng ZC, Guan J, Ding Y, Qian XL, Liao WT, Ding YQ and Liang L: Inhibition of ATG12-mediated autophagy by miR-214 enhances radiosensitivity in colorectal cancer. Oncogenesis 7: 16, 2018.

14. Penna E, Orso F and Taverna D: miR-214 as a key hub that controls cancer networks: Small player, multiple functions. J Invest Dermatol 135: 960-969, 2015.

15. Ling H, Pickard K, Ivan C, Isella C, Ikuo M, Mitter R, Spizzo R, Bullock M, Braicu C, Pileczki V, et al: The clinical and biological significance of miR-224 expression in colorectal cancer metastasis. Gut 65: 977-989, 2016.

16. Fernandez S, Risolino M, Mandia N, Talotta F, Soini Y, Incoronato M, Condorelli G, Banfi S and Verde P: miR-340 inhibits tumor cell proliferation and induces apoptosis by targeting multiple negative regulators of p27 in non-small cell lung cancer. Oncogene 34: 3240-3250, 2015.

17. Fang F, Chang RM, Yu L, Lei X, Xiao S, Yang H and Yang LY: MicroRNA-188-5p suppresses tumor cell proliferation and metastasis by directly targeting FGF5 in hepatocellular carcinoma. J Hepatol 63: 874-885, 2015.

18. Lima CR, Geraldo MV, Fuziwara CS, Kimura ET and Santos MF: MiRNA-146b-5p upregulates migration and invasion of different papillary thyroid carcinoma cells. BMC Cancer 16: 108, 2016.

19. Liao J, Liu R, Shi YJ, Yin LH and Pu YP: Exosome-shuttling microRNA-21 promotes cell migration and invasion-targeting PDCD4 in esophageal cancer. Int J Oncol 48: 2567-2579, 2016.

20. Guo X, Han T, Hu P, Guo X, Zhu C, Wang Y and Chang S: Five microRNAs in serum as potential biomarkers for prostate cancer risk assessment and therapeutic intervention. Int Urol Nephrol 50: 2193-2200, 2018.

21. Wang Q, Zhang H, Shen X and Ju S: Serum microRNA-135a-5p as an auxiliary diagnostic biomarker for colorectal cancer. Ann Clin Biochem 54: 76-85, 2017.

22. Zhu X, Han S, Wu S, Bai Y, Zhang N and Wei L: Dual role of twistl in cancer-associated fibroblasts and tumor cells promoted epithelial-mesenchymal transition of esophageal cancer. Exp Cell Res 375: 41-50, 2019.

23. Musavi Shenas MH, Eghbal-Fard S, Mehrisofiani V, Abd Yazdani N, Rahbar Farzam O, Marofi F and Yousefi M: MicroRNAs and signaling networks involved in epithelialmesenchymal transition. J Cell Physiol 234: 5775-5785, 2019.

24. Dong H, Weng C, Bai R, Sheng J, Gao X, Li L and Xu Z: The regulatory network of miR-141 in the inhibition of angiogenesis. Angiogenesis 22: 251-262, 2019.

25. Bedke J, Heide J, Ribback S, Rausch S, de Martino M, Scharpf M, Haitel A, Zimmermann U, Pechoel M, Alkhayyat H, et al: Microvascular and lymphovascular tumour invasion are associated with poor prognosis and metastatic spread in renal cell carcinoma: A validation study in clinical practice. BJU Int 121: 84-92, 2018.

26. Casasent AK, Schalck A, Gao R, Sei E, Long A, Pangburn W, Casasent T, Meric-Bernstam F, Edgerton ME and Navin NE: Multiclonal invasion in breast tumors identified by topographic single cell sequencing. Cell 172: 205-217.e12, 2018.

27. Zheng Y, Li S, Boohaker RJ, Liu X, Zhu Y, Zhai L, Li H, Gu F, Fan Y, Lang R, et al: A microRNA expression signature in taxane-anthracycline-based neoadjuvant chemotherapy response. J Cancer 6: 671-677, 2015.

(i) This work is licensed under a Creative Commons Attribution-NonCommercial-NoDerivatives 4.0 International (CC BY-NC-ND 4.0) License. 